\title{
MONITORING OF CHEMICAL CHANGES IN RED LENTIL SEEDS DURING THE GERMINATION PROCESS
}

\author{
ILDIKÓ SZEDLJAK *1 , ANIKÓ KOVÁCS ${ }^{1}$, GabRIELLA KUn-FARKAS ${ }^{2}$, BOtONd BeRNHARDT ${ }^{3}$, \\ SZABINA KRÁLIK ${ }^{1}$, AND KATALIN SZÁNTAI-KŐHEGYI ${ }^{1}$ \\ ${ }^{1}$ Department of Grain and Industrial Plant Processing, Szent István University, Villányi út 29-43, Budapest, \\ 1118, HUNGARY \\ ${ }^{2}$ Department of Brewing and Distilling, Faculty of Food Science, Szent István University, Villányi út 29-43, \\ Budapest, 1118, HUNGARY \\ ${ }^{3}$ Department of Soil Chemistry and Turnover, Institute for Soil Sciences and Agricultural Chemistry, Centre \\ for Agricultural Research, Hungarian Academy of Sciences, Herman Ottó út 15, Budapest, 1022 , \\ HUNGARY
}

\begin{abstract}
Red lentils are a very important raw material in the food industry due to their high protein content and high level of healthpromoting components. The nutritive value of red lentils is the most important attribute from a research point of view; it can be increased by germination, soaking as well as physical and biochemical processes. The antinutritive materials are reduced or denatured by the germination process and indigestible components become available to the human body. Heat treatment was applied to achieve different temperatures and increase the microbiological stability of germinating samples. The effect of heat treatment on the amounts of certain components and the activity of oxidative enzymes was tested during our experiments; the nutritional characteristics (water-soluble total polyphenol content (WSTPC), watersoluble protein content (WSPC), water-soluble antioxidant capacity, in addition to peroxidase and polyphenol oxidase enzyme activities) of different treatments in red lentil samples were monitored. The WSTPC in our samples ranged from $0.726 \mathrm{mg}$ Gallic Acid Equivalent GAE/g DW (DW being dry weight) to $1.089 \mathrm{mg}$ GAE/g DW, and the WSPC varied from $19.078 \mathrm{~g} / 100 \mathrm{~g}$ DW to $29.692 \mathrm{~g} / 100 \mathrm{~g}$ DW. Results showed that germination led to an increase in the WSTPC and WSPC. The peroxidase enzyme activity also exhibited an increase during germination which could result in deepening of the colour of the finished products. Germination resulted in the water-soluble antioxidant capacity of red lentil samples decreasing.
\end{abstract}

Keywords: red lentil, germination, antioxidant activity, protein, enzyme

\section{Introduction}

Lentils (Lens culinaris M.) are bushy annual plants of the legume family. Lentils are grown for the high protein content and high nutritive value of their lens-shaped seeds. Lentils are primarily a cool-season crop; they are moderately resistant to high temperatures and droughts. Lentils are characterized by their high levels of plant protein, complex carbohydrates (resistant starch, slowly digestible starch and oligosaccharides), fibres (soluble and insoluble) as well as very low sodium and fat content. Additionally, lentils are rich in B-vitamins, e.g. folate, thiamin and niacin, and key minerals, namely iron, potassium, magnesium and zinc, make them a highly nutritious food.

The most common types of lentils are red, green and black of which red and green are the most commonly traded. The cultivation and consumption of red lentils are considerable in Asian countries. On the other hand, con-

\footnotetext{
*Correspondence: ildiko.szedljak@gmail.com
}

sumer demand for red lentils in the Western Hemisphere is not high [1].

Red lentils are a valuable source of macronutrients (proteins, fats, carbohydrates) and other important components (phytochemicals: phytic acid, phenolic acids, flavonols, flavanols and condensed tannins). Lentils have demonstrated many health benefits, e.g. lowering the glycemic index and their gluten-free status for people with metabolic disorders. The consumption of lentils can also lead to weight loss, which is recommended for all overweight and obese individuals [2,3].

The germinated seeds and their compounds are possible components of functional foods. Functional foods play an important role in health promotion and disease prevention. Different scientific papers suggest that lentils provide protection against chronic diseases through a multitude of biological activities including anticancer, antioxidant and angiotensin-converting enzyme inhibition. Lentils also reduce blood lipid levels and the risk of developing cardiovascular diseases $[4,5]$. 
The nutritive value of lentil seeds can be improved by the germination process. Germination is a complex metabolic process during which the lipids, carbohydrates and storage proteins within seeds are broken down in order to obtain the necessary energy and amino acids. These changes influence the bioavailability of essential nutrients [6]. The presence of antinutritional factors might be reduced by germination. Red lentils have been gaining increasing attention due to their health benefits as part of the human diet and they are considered to be an excellent source of dietary antioxidants largely because of their high level of bioactive phytochemicals $[1,7]$

In Hungary, small-scale (20 seeds) red lentil germination experiments have already been conducted during which the effect of germination on the lectin content was studied [8]. The main purpose of our research was to examine the suitability of the germinated red-lentil grist as a raw material of dry pasta.

Red lentils were selected for our experiments due to their aforementioned favourable nutritional characteristics. In addition, its flour can be suitable in the development of gluten-free pasta products in the form of enrichment and gluten-free raw materials. The formation of more digestible water-soluble components was conduced by seed germination, but at the same time a loss may be observed due to the heat treatments (drying pasta) used in the manufacture of the products. The same loss may occur during the boiling process. Therefore, it is important to check for all kinds of changes that occur during heat treatment. The control of the activity of enzymes which generate oxidation processes is also essential during germination as is technological / kitchen-technological processing from the point of view of the expected quality of the finished products.

Developing food diversity by incorporating red lentil seeds and its flour into western diets is highly recommended.

\section{Experimental}

The aim of our study was to examine the chemical changes in red lentil seeds during the germination process. The effect of different heat treatments on the amount of certain components and the activity of oxidative enzymes were monitored. Moreover, a connection between the parameters and the extent to which these variables interact was sought.

\subsection{Samples and Measurements}

Samples $10 \mathrm{~kg}$ of raw organic whole red lentil was purchased from BiOrganik Online Kft. $3 \mathrm{~kg}$ of which was added to the germination device. $500 \mathrm{~g}$ of both soaked and sprouting seeds were sampled and heat-treated at three different temperatures. The heat-treated seeds were milled using a hammer grinder and then homogenized. The aqueous extracts were made from the control samples and the heat-treated grists.
Steeping, Germination and Heat Treatment Steeping and germination were performed in a SchmidtSeeger, KMA-A1-2008 micromalting plant. The micromalting plant was controlled by a personal computer with a special controlled by a personal computer with special software. During germination the temperature of the air was regulated and wetted with special jets.

During the steeping process compressed air was dispersed in the steeping water. Alternate wet and dry periods were implemented during steeping, because during the latter the oxygen uptake of grains is more effective. Wet steeping lasted for 3 hours at $20{ }^{\circ} \mathrm{C}$ with aerations of 6.67 minutes in duration every 8 minutes. This was followed by a 2 hour-long dry period at $22{ }^{\circ} \mathrm{C}$ with humidification. The second 2 -hour-long wet period was performed at $20^{\circ} \mathrm{C}$. Steeping was stopped when an adequate moisture content was achieved. Germination lasted for 96 hours at $22{ }^{\circ} \mathrm{C}$ with humidification. During the first 48 hours, the germinating seeds were rotated 30 times every two hours, then every three hours. Germinating seeds were not sprayed during the process.

Germinating red lentil samples were taken daily at the same time. Heat treatment was applied at different temperatures $\left(60{ }^{\circ} \mathrm{C}, 80{ }^{\circ} \mathrm{C}, 100{ }^{\circ} \mathrm{C}\right)$ in order to increase the microbiological stability of germinating samples. The effect of heat treatment on the amount of certain components and the activity of oxidative enzymes was tested during our experiments.

Chemical Analysis The samples were homogenized and $0.10 \mathrm{ml}$ of distilled water was added to each sample. The centrifugation process was conducted after extraction for 10 minutes at $4{ }^{\circ} \mathrm{C}$ and $10,000 \mathrm{rpm}$. The watersoluble polyphenolic content was measured by colorimetric analysis using Folin \& Ciocalteu's phenol reagent [9] and the results were expressed in Gallic Acid Equivalent (GAE) (mg GAE/g DW - DW being dry weight). The WSPC was measured by a method discovered by Layne [10].

The water-soluble antioxidant activity was determined using a Ferric Reducing Antioxidant Power (FRAP) Assay Kit [11]. The polyphenol oxidase (PPO) enzyme activity was measured by using a synthetic substrate, pyrocatechol. The oxidized form of the substrate can be synthesized photometrically at $420 \mathrm{~nm}$ by a spectrophotometer [12]. The peroxidase (POD) enzyme activity of the extracts was determined using o-Dianisidine as a hydrogen donor in sodium acetate $(\mathrm{pH}$ 5.1) [13]. The reagents for the chemical measurements were provided by Sigma-Aldrich Kft.

Statistical Methods All of the measurements were replicated five times. The Kruskal-Wallis test was applied to calculate the exact $p$-value $(\alpha=0.05)$ and Dunn's post hoc pair-wise test was chosen with an adjustment by Bonferroni. The relationship between the parameters was determined by Spearman's rank correlation coeffi- 


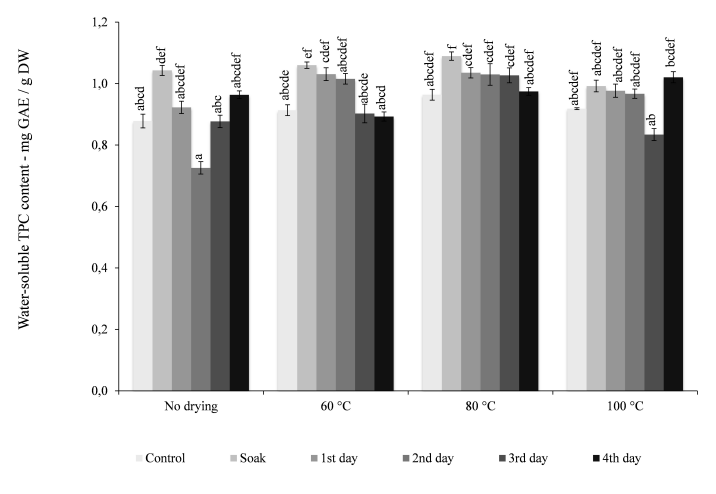

Figure 1: Water-soluble total polyphenol content in red lentil samples. Different letters indicate significant differences between treatments $(p \leq 0.05)$.

cient (non-parametric equivalent of Pearson's correlation coefficient) $(\alpha=0.05)$ using the XLSTAT-Sensory solution software, version 2013.1.01 (Addinsoft, 28 West 27th Street, Suite 503, New York, NY 10001, USA).

During the correlation test the correlation between the variables regardless of their units was examined.

\section{Results and Evaluation}

\subsection{Water-soluble total polyphenol content (WSTPC)}

Zhang et al. [14] measured the total polyphenol content (soluble and insoluble in water) using Folin Ciocalteu's reagent in raw red-lentil extracts $(5.04 \pm 0.36 \mathrm{mg} \mathrm{GAE} / \mathrm{g}$ DW $-7.02 \pm 0.48 \mathrm{mg} \mathrm{GAE} / \mathrm{g} \mathrm{DW})$. According to their data all extracts of lentils cultivated in Canada were significantly different from each other. In contrast to this TPC values changed over a very narrow range (from 5.9 $\pm 0.1 \mathrm{mg} \mathrm{GAE} / \mathrm{g} \mathrm{DW}$ to $5.93 \mathrm{mg} \mathrm{GAE} / \mathrm{g} \mathrm{DW}$ ) in the samples of red-lentil flour tested [15-17]. The results of TPC are shown in Fig. 1. The WSTPC in our samples ranged from $0.726 \mathrm{mg} \mathrm{GAE} / \mathrm{g}$ DW to $1.089 \mathrm{mg} \mathrm{GAE} / \mathrm{g}$ DW. Our WSTPC values were 5 to 10 times smaller than in the aforementioned experiments.

By comparing the control and soaked samples, it can be observed that the WSTPC increased during the soaking process. These values were higher than the measured data from germinated samples (Fig. 1).

According to our experiments heat treatment at high temperatures $\left(80^{\circ} \mathrm{C}\right.$ and $\left.100^{\circ} \mathrm{C}\right)$ equalized the WSTPC values in red lentil samples. Furthermore, germination and heat treatments did not effect the WSTPC of the seeds.

\subsection{Water-soluble antioxidant capacity}

The results of water-soluble antioxidant capacity were measured using a FRAP Assay Kit. The values ranged between $0.177 \mathrm{mg}$ Ascorbic Acid Equivalent (AAE)/g DW

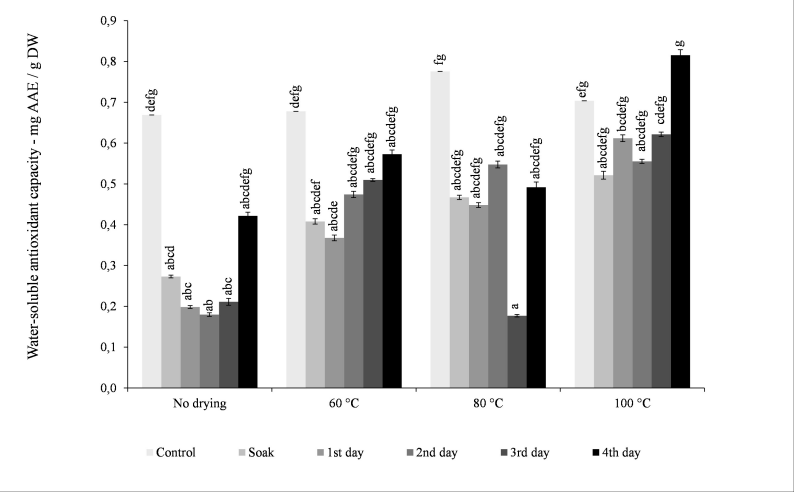

Figure 2: Water-soluble antioxidant capacity of red lentil samples. Different letters indicate significant differences between treatments $(p \leq 0.05)$.

and $0.815 \mathrm{mg} \mathrm{AAE} / \mathrm{g}$ DW. As a result of the germinating process, the antioxidant capacity of the samples was significantly reduced compared to that of the control sample. However, treatment at a high temperature $\left(100{ }^{\circ} \mathrm{C}\right)$ led to a further increase in the amount of new water-soluble components with antioxidant capacity. Samples that were not dried during the first 3 days were significantly different from the control samples in all of the categories. Moreover, they differed from the sample dried at $100{ }^{\circ} \mathrm{C}$ on the 4th day (Fig. 2).

The highest water-soluble antioxidant capacities were measured in the control samples, except for the control sample treated at $100{ }^{\circ} \mathrm{C}$. By comparing control samples to germinated samples, it is evident that the germinating process did not result in an increase in the water-soluble antioxidant capacity. Our results showed that whilst being soaked the water-soluble antioxidant capacity started to decrease.

The water-soluble antioxidant capacity in the heattreated sample on the $3 \mathrm{rd}$ day of germination at $80^{\circ} \mathrm{C}$ decreased drastically compared to the control sample. The same change occurred with the samples that were not dried. Nevertheless, the significant decrease had already occurred on the 1st day of germination.

No correlation was found between the WSTPC and water-soluble antioxidant capacity.

\subsection{Water-soluble protein content (WSPC)}

WSPCs, given in Fig. 3, ranged from $19.078 \mathrm{~g} / 100 \mathrm{~g}$ DW (dry weight) to $29.692 \mathrm{~g} / 100 \mathrm{~g} \mathrm{DW}$.

By comparing the control and soaked samples, it is evident that the WSPC increased during the soaking process. In the case of samples that were not dried in addition to those treated at $80{ }^{\circ} \mathrm{C}$ and $100{ }^{\circ} \mathrm{C}$, no significant differences were observed between treatments except for samples treated at $60{ }^{\circ} \mathrm{C}$ where those soaked and on their 2nd day of germination had significantly higher values compared to the control sample. The highest WSPC was 


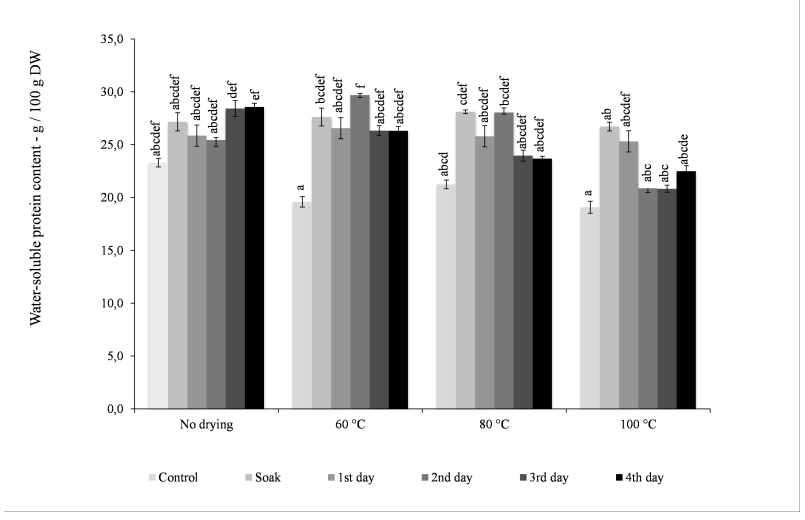

Figure 3: Water-soluble protein content in red lentil samples. Different letters indicate significant differences between treatments $(p \leq 0.05)$.

measured on the 2 nd day of germination at $60^{\circ} \mathrm{C}$, which was significantly higher than all the heat-treated control samples as well as samples treated at $100{ }^{\circ} \mathrm{C}$ except for the value on the 1st day of germination.

As the germination process advanced - especially on the 3rd and 4th days - the WSPC of samples heat-treated at $80{ }^{\circ} \mathrm{C}$ and $100{ }^{\circ} \mathrm{C}$ started to decrease compared to the same phenophases of those that were not dried or heattreated at $60{ }^{\circ} \mathrm{C}$. This may be explained by the fact that plant proteins are more easily degraded at higher temperatures over prolonged periods of time. A negative correlation was observed between the WSPC and water-soluble antioxidant capacity.

The total protein content was determined using the Dumas method as described by Hefnawy [18]. In this study the total protein content was $26.6 \pm 0.50 \mathrm{~g} / 100$ g DW and the effect of the heat treatment was insignificant.

\subsection{Peroxidase (POD) Enzyme Activity}

The changes in POD enzyme activity of red-lentil samples are shown in Fig. 4. The POD adversely affects the nutritive value, taste, texture and colour of food products. These enzymes are referred to as heat-tolerant enzymes and can regain their activity following heat treatment and storage (Fig. 4).

POD enzyme activity ranged from $10.815 \mathrm{U} / \mathrm{g}$ DW to 215.785 U/g DW with statistically significant differences. The highest value $(215.785 \mathrm{U} / \mathrm{g} \mathrm{DW})$ was found in the sample dried at $100{ }^{\circ} \mathrm{C}$ on the 4th day.

The samples that were not dried or heat-treated were identical to each other on the same level (control, soaked, 1st-4th day). POD activity progressively increased during the germination process in almost all cases. The POD activity of the sample dried at $100{ }^{\circ} \mathrm{C}$ was 20 -fold higher than that of the control sample. The POD activity of different tempered lentil samples was also measured by Pathiratne et al. [19] and their maximum value was 186.4

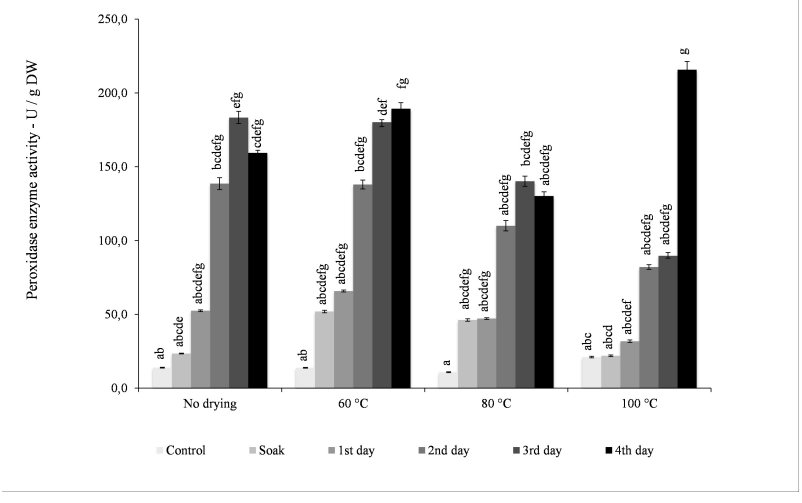

Figure 4: Peroxidase enzyme activity of red lentil samples. Different letters indicate significant differences between treatments $(p \leq 0.05)$.

U/g protein. However, in another study by Świeca et al. [20], the POD activity of germinated lentil samples was much higher than the aforementioned ones, $10.3 \pm 0.24$ $\mathrm{kU} / \mathrm{mg}$ protein.

Elevated temperatures of heat treatment resulted in an increase in the POD activity during the germination process.

\subsection{Polyphenol oxidase (PPO) enzyme activ- ity}

PPOs and PODs are the most studied enzymes in fruit and vegetables. Świeca et al. [20] studied the PPO enzyme activity in sprouts of lentils according to the method described by Galeazzi et al. [21] and measured $2.24 \pm 0.05$ $\mathrm{kU} / \mathrm{mg}$ protein. They reported that enzymatic markers of the stress metabolism of plants, e.g. PPO activities, did not differ significantly between sprouts. In our study a catechol substrate was also used but no PPO enzyme activity was detected in the samples.

\section{Conclusion}

Of all the parameters studied, the WSPC of red lentils strongly correlated with the values of water-soluble antioxidant capacity measured using the FRAP Assay Kit (data not shown). The correlation is inversely proportional, hence, the greater the WSPC, the lower the watersoluble antioxidant capacity. Seed germination is one of the most important stages in the life cycle of plants and germinated seeds may be a useful source of healthy food. Germinated seeds are very complex living matrices and it is very difficult to understand the biochemical changes that occur during sprouting. Further studies on the germination process of red lentils are needed to help understand and identify the important parameters that are able to describe such changes.

Functional foods play an important role in terms of consumer acceptance [22], thus, a more suitable approach 
may well be sensory evaluation in the case of our redlentil samples. The latest development methodologies should be used, namely preference mapping methods, Just-About-Right (JAR) scaling and eye-tracking methods [23-25].

\section{REFERENCES}

[1] Zhang, B.; Deng, Z.; Tang, Y.; Chen, P.; Liu, R.; Ramdath, D. D.; Liu, Q.; Hernandez, M.; Tsao, R.: Fatty acid, carotenoid and tocopherol compositions of 20 Canadian lentil cultivars and synergistic contribution to antioxidant activities. Food Chem., 2014 161, 296-304. DOI: 10.1016/j.foodchem.2014.04.014

[2] Papanikolaou, Y.; Fulgoni, V. L.: Bean consumption is associated with greater nutrient intake, reduced systolic blood pressure, lower body weight, and a smaller waist circumference in adults: results from the National Health and Nutrition Examination Survey 1999-2002. J. Am. Coll. Nutr., 2008 27(5), 569576. DOI: $10.1080 / 07315724.2008 .10719740$

[3] Sravanthi, B.; Jayas, D. S.; Alagusundaram, K.; Chelladurai, V.; White, N. D. G.: Effect of storage conditions on red lentils. J. Stored Prod. Res. 2013 53, 48-53. DOI: 10.1016/j.jspr.2013.01.004

[4] Duane, W. C.: Effects of legume consumption on serum cholesterol, biliary lipids, and sterol metabolism in humans. J. Lipid Res., 1997 38(6), $1120-1128$.

[5] Shepherd, J.; Cobbe, S. M.; Ford, I.; Isles, C. G.; Lorimer, A. R.; MacFarlane, P. W.; McKillop, J. H.; Packard, C. J.: Prevention of coronary heart disease with pravastatin in men with hypercholesterolemia. N. Engl. J. Med., 1995 333(20), 1301-1308. DOI: 10.1056/NEJM199511163332001

[6] Urbano, G.; Lopez-Jurado, M.; Hernandez, J.; Fernandez, M.; Moreu, M. C.; Frias, J.; Diaz-Pollan, C.; Prodanov, M.; Vidal-Valverde, C.: Nutritional assessment of raw, heated and germinated lentils. J. Agric. Food Chem., 1995 43(7), 1871-1877. DOI: 10.1021/jf00055a022

[7] Zou, Y.; Chang, S. K. C.; Gu, Y.; Qian, S. Y.: Antioxidant activity and phenolic compositions of lentil (Lens culinaris var. Morton) extract and its fractions. J. Agric. Food Chem., 2011 59(6), 22682276. DOI: $10.1021 / \mathrm{jf} 104640 \mathrm{k}$

[8] Cuadrado, C.; Gelencsér, É.; Perdoza, M. M.; Ayet, G.; Muzquiz, M.; Puszati, A.; Hajós, Gy.; Burbano, C.: Influence of germination on lectin in Lens culinaris seeds. Acta Aliment., 2000 29(3), 231-240. DOI: 10.1556/AAlim.29.2000.3.3

[9] Singleton, V. L.; Rossi, J. A.: Colorimetry of total phenolics with phosphomolybdic-phosphotungstic acid reagents. Am. J. Enol. Viticult., 1965 16(3), 144-158.

[10] Layne, E.: Spectrophotometric and turbidimetric methods for measuring proteins. Chapter in
Methods Enzymol., 1957, pages 447-454. DOI: 10.1016/S0076-6879(57)03413-8

[11] Benzie, I. F. F.; Strain, J. J.: The ferric reducing ability of plasma (FRAP) as a measure of "antioxidant power": the FRAP assay. Anal. Biochem., 1996 239(1), 70-76. DOI: 10.1006/abio.1996.0292

[12] Watson, R. A.; Flurkey, W. H.: Use of contact prints for recording polyphenoloxidase isoenzymes separated by electrophoresis. J. Sci. Food Agric., 1986 37(8), 791-796. DOI: 10.1002/jsfa2740370812

[13] Björkstén, F.: Participation of horseradish oxyperoxidase (compound III) in interenzymic reaction steps. Biochem. Biophys. Acta, 1968 151(1), 309311. DOI: 10.1016/0005-2744(68)90196-4

[14] Zhang, B.; Deng, Z.; Tang, Y.; Chen, P.; Liu, R.; Ramdath, D. D.; Liu, Q.; Hernandez, M.; Tsao, R.: Fatty acid, carotenoid and tocopherol compositions of 20 Canadian lentil cultivars and synergistic contribution to antioxidant activities. Food Chem., 2014 161, 296-304. DOI: 10.1016/j.foodchem.2014.04.014

[15] Xu, B. J.; Yua, S. H.; Chang, S. K. C.:Comparative analyses of phenolic composition, antioxidant capacity, and color of cool season legumes and other selected food legumes. J. Food Sci. 2007 72(2), 167-177. DOI: 10.1111/j.1750-3841.2006.00261.x

[16] Boye, J. I.; Aksay, S.; Roufik, S.; Ribéreau, S.; Mondor, M.; Farnworth, E.; Rajamohamed, S. H.: Comparison of the functional properties of pea, chickpea and lentil protein concentrates processed using ultrafiltration and isoelectric precipitation techniques. Food Res. Int., 2010 43(2), 537-554. DOI: 10.1016/j.foodres.2009.07.021

[17] Shaheen, N.; Goto, M.; Watanabe, J.; TakanoIshikawa, Y.: Antioxidant capacity and total phenol content of commonly consumed indigenous foods of Asian tropical regions. J. Food Sci. Eng., 2012 2(4), 187-195. DOI: 10.17265/2159-5828/2012.04.001

[18] Hefnawy, T. H.: Effect of processing methods on nutritional composition and anti-nutritional factors in lentils (Lens culinaris). Ann. Agric. Sci., 2011 56(2), 57-61. DOI: 10.1016/j.aoas.2011.07.001

[19] Pathiratne, S. M.; Shand, P. J.; Pickard, M.; Wanasundara, J. P. D.: Generating functional property variation in lentil (Lens culinaris) flour by seed micronization: Effects of seed moisture level and surface temperature. Food Res. Int., 2015 76(1), 122 131. DOI: 10.1016/j.foodres.2015.03.026

[20] Świeca, M.; Sęczyk, Ł.; Gawlik-Dziki, U.: Elicitation and precursor feeding as tools for the improvement of the phenolic content and antioxidant activity of lentil sprouts. Food Chem., 2014 161, 288295. DOI: 10.1016/j.foodchem.2014.04.012

[21] Galeazzi, M. A. M.; Sgarbieri, V. C.; Costantinides, S. M.: Isolation, purification and physiochemical characterization of polyphenoloxidases (PPO) from dwarf variety of banana (Musa Cavendishii, L.). J. Food Sci., 1981 46(1), 150-155. DOI: 10.1111/j.13652621.1981.tb14551.x 
[22] Bagdi, A.; Tóth, B.; Lôrincz, R.; Szendi, Sz.; Gere, A.; Kókai, Z.; Sipos, L.; Tömösközi, S: Effect of aleurone-rich flour on composition, baking, textural, and sensory properties of bread. LWT - Food Sci. Tech., 2016 65, 762-769. DOI: 10.1016/j.1wt.2015.08.073

[23] Gere, A.; Kovács, S.; Pásztor-Huszár, K.; Kókai, Z.; Sipos, L.: Comparison of preference mapping methods: a case study on flavoured kefirs. J. Chemom., 2014 28(4), 293-300. DOI: 10.1002/cem.2594
[24] Gere, A.; Sipos, L.; Héberger, K.: Generalized pairwise correlation and method comparison: Impact assessment for JAR attributes on overall liking. Food Qual. Prefer., 2015 43, 88-96. DOI: 10.1016/j.foodqual.2015.02.017

[25] Gere, A.; Danner, L.; De Antoni, N.; Kovács, S.; Dürrschmid, K.; Sipos, L.: Visual attention accompanying food decision process: An alternative approach to choose the best models. Food Qual. Prefer., 2016 51, 1-7. DOI: 10.1016/j.foodqual.2016.01.009 